\title{
In memoriam Josipu Defilippisu (1930. - 2013.)
}

Upravo u vrijeme kada smo sredinom lipnja dogovarali pojedinosti oko jubilarnog broja našeg časopisa te proslave pedesetogodišnjice njegovog izlaženja, pristigla nam je iz Splita tužna vijest da je 12. lipnja, s netom navršene 83 godine života, umro jedan od naših najvrsnijih suradnika, dugogodišnji član Uredništva i sudionik u ključnim ruralno-sociološkim istraživačkim projektima - prof. dr. sc. Josip Defilippis, kojeg smo od milja zvali Barba.

Josip Defilippis rođen je 6. lipnja 1930. godine u Nerežišću na otoku Braču. Osnovnu i srednju školu pohađao je u Splitu, a diplomirao je na Poljoprivredno-šumarskom fakultetu u Zagrebu. Šezdesetih godina tri je akademske godine proveo na poslijediplomskim studijima ruralnog razvoja u Francuskoj (Montpellier) i Italiji (Bari). Doktorirao je na temi regionalnog agrarnog planiranja 1971. godine. U Institutu za jadranske kulture i melioraciju krša u Splitu utemeljio je i vodio Zavod za ekonomiku poljoprivrede i sociologiju sela, a dugi niz godina bio je i ravnatelj Instituta. Na Ekonomskom fakultetu Sveučilišta u Splitu, u zvanju redovitog profesora, predavao je kolegije „Ekonomika mediteranske poljoprivrede“ i „Ekologija i razvitak“.

Josip Defilippis napisao je nekoliko knjiga i velik broj članaka iz područja sociologije sela i ekonomike poljoprivrede.

Za knjigu „Ekonomika poljoprivrede“ 2003. godine dobio je znanstvenu nagradu „Josip Juraj Strossmayer“, koju je dodijelio HAZU i Zagrebački velesajam.

Za nas je ključna činjenica da je Josip Defilippis bio dugogodišnji član Uredništva i izuzetno vrijedan suradnik časopisa Sociologija sela u kojem je objavio brojne priloge.

Bio je najbolji poznavalac sociološke i ekonomske problematike jadranskog seoskog područja. Stoga je u časopisu Sociologija sela Josip Defilippis glavni promotor jadranske (mediteranske) ruralne komponente. Pored socioloških i ekonomskih, pažnju je posvećivao prostornim i ekološkim aspektima ruralnih sredina, interpenetraciji ruralnog i urbanog, poljoprivrednog i nepoljoprivrednog, prirodnog i tehničkog elementa.

Prisjetio sam se mnogih trenutaka dugogodišnje suradnje, a posebno naših razgovora o budućim ruralnim projektima. Primjera radi, bilo nam je žao što nismo uspjeli realizirati zamisao o istraživanju strukture vlasništva poljoprivrednog zemljišta, s naglaskom na tzv. vlasnički apsentizam, što smo radno nazivali „Anketom parcele“. No ljudsko vrijeme neumitno teče pa dođe trenutak kada, kako reče pjesnik, „[v] alja nama preko rijeke“, tamo kuda je, prije Barbe, već otišlo nekoliko vrlih ruralista naše generacije. 
Hrvatska ruralna sociologija smrću Josipa Defilippisa izgubila je još jednog od svojih bardova koji je svojim doprinosom obilježio posljednja desetljeća njenog razvoja.

Mi, njegovi prijatelji i suradnici, uvijek ćemo se sjećati mudrog i plemenitog Barbe, s kojim je bila čast i zadovoljstvo surađivati.

Vlado Puljiz 